УДК 347.453.6

DOI

\author{
М.П.Тиндик \\ orcid.org/0000-0001-9898-3356 \\ аспірант кафедри цивільного права № 2 \\ Національного юридичного університету імені Ярослава Мудрого
}

\title{
ЗМІСТ ОБОВ'ЯЗКУ НАЙМОДАВЦЯ З ПЕРЕДАННЯ ТРАНСПОРТНОГО ЗАСОБУ ЗА ДОГОВОРОМ ПРОКАТУ ТРАНСПОРТНОГО ЗАСОБУ
}

Постановка проблеми. Головним обов'язком наймодавця за договором прокату транспортного засобу є обов'язок з передання транспортного засобу у володіння та користування наймача. Згаданий обов'язок випливає із суті зазначеного договору, який належить до договорів про передання майна в користування та визначений ст. 787 Цивільного кодексу (далі - ЦК) України, якою встановлено, що за договором прокату наймодавець, який здійснює підприємницьку діяльність із передання речей у найм, передає або зобов'язується передати рухому річ наймачеві в користування за плату на певний строк [1]. Без виконання наймодавцем цього обов'язку подальший розвиток зобов'язання, що виникає на підставі договору прокату транспортного засобу, $є$ неможливим. Маючи на увазі саме правовідошення зі згаданого договору, Д.С. Левенсон слушно зазначив, що без передання в користування транспортних засобів не може бути договору оренди [2, с. 44].

Зміст, особливості та проблеми виконання наймодавцем обов' язку з передання транспортного засобу у прокат зумовлені особливістю його предмета. Вимоги до стану окремих видів транспортних засобів, що визначають можливість їх використання, установлені законом. Також особливість цього предмета визначальним чином впливає на строк, місце та спосіб виконання досліджуваного обов'язку наймодавця.

Актуальність теми зумовлена тим, що дослідження змісту цього обов'язку як у правовідносинах найму взагалі, так і у правовідносинах найму транспортного засобу зокрема не враховують його специфіки у правовідносинах, що виникають із договору прокату транспортного засобу, особливо щодо таких досить нових видів прокату цих засобів, як каршерінг.

Аналіз останніх досліджень і публікацій. Питання про зміст обов'язку наймодавця з передання предмета найму, зокрема і транспортного засобу, розглядали Д.С. Левенсон, О.С. Іоффе, М.Г. Проніна, М.В. Мороз, Е.В. Вакулович, І.А. Чуркін, I.P. Калаур, А.В. Федорончук, Л.Л. Тарасенко й інші вчені.

Водночас правовому аналізу змісту обов'язку наймодавця 3 передання транспортного засобу за договором прокату транспортного засобу було приділено не досить уваги, а отже, це питання $€$ актуальним та потребує подальшого дослідження.

Метою статті є загальне дослідження й аналіз змісту обов'язку наймодавця з передання транспортного засобу за договором прокату транспортного засобу.

Виклад основного матеріал дослідження. Переданням у прокат транспортного засобу є дії наймодавця, які спрямовані на переміщення цього об'єкта з його майнової сфери до майнової сфери наймача [3, с. 103]. Водночас не можемо погодитися $з$ думкою I.A. Чуркіна про те, що таке передання може бути лише активною дією [4, с. 88]. Як приклад можна навести передання легкового автомобіля в такому різновиді прокату транспортного засобу, як каршерінг. Після реєстрації на сайті або в мобільному додатку наймодавця та укладання договору наймач отримує доступ до особистого кабінету, де оформлюються поїздки. У застосунку, який встановлюється на смартфон, відображаються всі вільні натепер автомобілі, які наймодавець може передати для користування. Після того, як наймач вибере автомобіль за допомогою електронного засобу, він може відчинити двері автомобіля через відповідний додаток у смартфоні. Ключ автомобіля вже стоїть у замку запалення й автомобіль готовий до використання. Як бачимо, наймодавець не вчиняє активних дій щодо передання відповідного транспортного засобу [5].

У разі передання транспортного засобу неабияке значення мають місце та строк передання, які різняться залежно від того, який саме вид транспорту передається у прокат.

Що стосується місця виконання зобов'язання 3 передання транспортного засобу, то варто зазначити таке. Відповідно до ч. 1 ст. 532 ЦК України, місце виконання зобов'язання встановлюється в договорі [1]. Таким є загальне правило щодо місця виконання будь-яких зобов'язань, зокрема й щодо зобов'язання, що виникає з договору прокату транспортного засобу. Якщо місце виконання зобов'язання не встановлено в договорі, виконання провадиться: за зобов'язанням про передання товару (майна), що виникає на підставі інших правочинів, - за місцем виготовлення або зберігання товару / майна, якщо це місце було відоме кредиторові на момент виникнення зобов'язання; 
за іншим зобов'язанням - за місцем проживання (місцезнаходження) боржника. Згідно із приписами ч. 2 цієї ж статті, зобов' язання може бути виконане в іншому місці, якщо це встановлено актами цивільного законодавства або випливає із суті зобов'язання чи звичаїв ділового обороту [1].

Під час виконання наймодавцем обов'язку 3 передання транспортного засобу за договором прокату варто враховувати той факт, що ним завжди виступає суб’єкт підприємницької діяльності, який здійснює таку діяльність із передання речей у найм. Отже, таким суб'єктом може бути не лише фізична особа-підприємець, але і юридична особа. Виконання згаданого зобов' язання не завжди проводиться за місцем проживання фізичної особи - підприємця або місцезнаходженням юридичної особи. Зокрема, якщо місце передання транспортного засобу наймодавцем наймачеві за договором прокату не встановлено в договорі, він може передаватися в місці, де його постійно зберігає наймодавець (так передаються транспортні засоби, що знаходяться в гаражі орендодавця) [7, с. 96]. Зазвичай транспортні засоби передаються наймодавцем наймачеві в пунктах прокату або в інших спеціально відведених для цього місцях, залежності від виду того чи іншого транспортного засобу, як-от прокатні бази, прокатні пункти водних атракціонів (що характерно для водних транспортних засобів) тощо. Варто звернути увагу на той факт, що науковці мають різне наукове бачення щодо визначення пункту прокату. Так, А.В. Федорончук зауважує, що зазвичай передання речі відбувається в пункті прокату, тобто за місцем їх зберігання [8, с. 135]. Дещо по-іншому до бачення пункту прокату підходить I.P. Калаур, який зазначає, що пункти прокату можуть бути як юридичними особами, так і структурними підрозділами юридичної особи [9, с. 190]. Надалі він зазначає, що в пунктах прокату (на підприємстві, в організації) у зручному для огляду місці повинні бути: правила побутового обслуговування населення; тарифи на прокат предметів культурно-побутового призначення та господарського вжитку, затверджені у встановленому порядку [9, с. 191]. На нашу думку, не варто ототожнювати місце, у якому юридична особа здійснює свою діяльність із передання речей у прокат, та саму юридичну особу, її структурні підрозділи. Також варто додати, що далеко не завжди місце зберігання наймодавцем транспортних засобів та пункт прокату збігаються за місцезнаходження, зокрема, після укладення договору прокату транспортного засобу наймодавець може доставити згаданий засіб залежно від його виду за місцем проживання наймача, може передати в іншому, визначеному домовленістю сторін, місці. Наприклад, у разі каршерінгу наймач за допомогою мобільного сервісу сам обирає найбільш зручне для нього місцезнаходження автомобіля в межах даного населеного пункту. Зазвичай автомобілі розміщуються на території, позначеній знаком паркування.

Велике значення для належного виконання обов'язку наймодавця з передання транспортного засобу в користування наймачеві має строк його виконання. Від строку виконання наймодавцем згаданого обов'язку залежить подальший розвиток правовідносин із прокату транспортного засобу, оскільки саме з моменту передання транспортного засобу в наймача з'являється можливість його використання, виникають відповідні обов'язки у правовідношенні з договору прокату (використовувати транспортний засіб за цільовим призначенням, забезпечувати його збереження в нормальному стані тощо).

Відповідно до ст. 765 ЦК України, наймодавець зобов' язаний передати наймачеві майно в користування негайно або у строк, установлений договором найму.

Якщо передання транспортного засобу у строк, установлений договором прокату, є очевидним та зрозумілим, то обов’язок передати транспортний засіб негайно викликає деякі запитання. На некоректність такого формулювання звернув увагу I.A. Чуркін, який зазначив, що з невиконанням зобов'язання найму в належний строк пов'язується ціла низка правових наслідків: наймач має право за своїм вибором: 1) вимагати від наймодавця передання майна і відшкодування збитків, завданих затримкою; 2) відмовитися від договору найму і вимагати відшкодування завданих йому збитків (ст. 766 ЦК України). Отже, постає проблема визначення моменту, з якого обов'язок щодо негайного передання транспортного засобу в найм є порушеним; з якого моменту обраховувати затримку та нараховувати збитки, завдані несвоєчасним переданням цього транспортного засобу в користування; нарешті, з якого моменту починається в даному разі перебіг строку позовної давності. Законодавець, мабуть, мав на увазі, що предмет найму має передаватися одразу ж після укладення договору найму. Однак для цього наймодавець повинен здійснити ще якісь фактичні дії, спрямовані на виконання цього обов'язку (привести транспортний засіб у стан, необхідний, за договором, для передачі, доставити цей транспортний засіб у місце передачі тощо). Для здійснення цих дій також необхідний розумний строк [4, с. 89].

На нашу думку, негайна (невідкладна) передача наймодавцем транспортного засобу у прокат є більш характерною для реального договору прокату транспортного засобу, тоді як у разі консенсуального договору строк передання транспортного засобу варто обумовлювати в договорі, оскільки між укладенням договору та переданням 
транспортного засобу в цьому разі все ж таки проходить певний період часу, можливо, і незначний, але розумно необхідний для вчинення сторонами відповідних дій.

Законом встановлено вимоги щодо якості транспортного засобу, який передається в користування за договором прокату. У ч. 1 ст. 767 ЦК України визначено загальні вимоги до якості речі, яка передається в найм. Згідно із цією нормою, наймодавець зобов'язаний передати наймачеві річ у комплекті і у стані, що відповідають умовам договору найму та її призначенню [1].

Відповідно до п. 13 ст. 1 Закону України «Про захист прав споживачів», належна якість товару, роботи або послуги - властивість продукції, яка відповідає вимогам, установленим для цієї категорії продукції в нормативно-правових актах, і умовам договору зі споживачем [11].

У ст. 6 згаданого Закону розкривається зміст права споживача на належну якість продукції. Зокрема встановлено, що продавець (виробник, виконавець) зобов'язаний передати споживачеві продукцію належної якості, а також надати інформацію про цю продукцію; продавець (виробник, виконавець) на вимогу споживача зобов'язаний надати йому документи, які підтверджують належну якість продукції; вимоги до продукції щодо їі безпеки для життя, здоров'я i майна споживачів, а також навколишнього природного середовища встановлюються нормативно-правовими актами, зокрема й технічними реглламентами [10].

У п. 99 Статуту автомобільного транспорту Української Радянської Соціалістичної Республіки унормовано, що прокатні організації повинні надавати наймачеві за договором прокату технічно справні автомобілі, у стані, який відповідає правилам технічної експлуатації автомобільного транспорту і Правилам дорожнього руху [11].

У п. 2.7 Порядку надання в тимчасове користування громадянам предметів культурно-побутового та господарського вжитку, затвердженого наказом Українського союзу об’єднань підприємств та організацій побутового обслуговування населення від 16 грудня 1999 р. № 46 (який поширюється на послуги прокату водних транспортних засобів), визначено, що наймодавець зобов'язаний видавати предмети прокату, придатні для експлуатації. У п. 4.2 цього ж Порядку встановлено таке: наймодавець зобов'язаний передати наймачеві предмет прокату, який відповідає вимогам нормативно-технічної документації. Згідно ж із п. 5.3 згаданого нормативного акта, цей Порядок не поширюється на послуги прокату дорожніх транспортних засобів [12].

Відповідно до ст. 10 Закону України «Про транспорт», транспортні засоби повинні відповідати вимогам безпеки, охорони праці й екології, державним стандартам, мати відповідний сертифікат [13].

Залежно від виду транспортного засобу спеціальним законодавством може бути встановлено більш детальні вимоги щодо технічного стану транспортного засобу, його комплектності тощо. Так, наприклад, забороняється експлуатація транспортних засобів за наявності технічних несправностей: рульового керування, гальмової системи, коліс і шин, зовнішніх світлових приладів, склоочисників і склообмивачів вітрового скла, двигуна та деяких інших елементів конструкції (відсутні дзеркала заднього виду); якщо відсутня медична аптечка, ремені безпеки, працездатний вогнегасник, якщо їх установка передбачена конструкцією, відсутній передбачений конструкцією бампер або задній захисний пристрій тощо (п. 3.4. Правил дорожнього руху) [14].

Очевидно, що в разі, якщо транспортний засіб заборонено до експлуатації Правилами дорожнього руху через невідповідність технічним вимогам, то його якість $є$ неналежною, він не може бути переданий наймодавцем наймачеві за договором прокату, оскільки використання його за цільовим призначенням $є$ неможливим.

Комплектність транспортного засобу, який передається у прокат, визначається за правилами ст. 186 ЦК України, якою встановлено, що річ, призначена для обслуговування іншої / головної речі і пов'язана з нею спільним призначенням, $€$ ïi приналежністю. Приналежність слідує за головною річчю, якщо інше не встановлено договором або законом [1]. Більш конкретні вимоги щодо комплектності встановлюються виробниками транспортних засобів та, залежно від їхнього виду, відповідними нормативними актами, які встановлюють правила експлуатації цих об'єктів (наприклад, Правила дорожнього руху для дорожніх транспортних засобів тощо).

Договором прокату транспортного засобу можуть бути встановлені додаткові вимоги щодо комплектності транспортного засобу, який передається в користування наймодавцем наймачеві. Так, наприклад, може бути обумовлено наявність дитячого крісла (або декількох) в автомобілі, який передається у прокат, багажника на його даху, навігатора тощо.

Разом із транспортним засобом наймодавець повинен передати наймачеві всі супроводжувальні документи на нього, передусім ті, що підтверджують правомірність володіння транспортним засобом і обов'язково мають бути в наявності в особи, яка керує ним, відповідно до вимог чинного законодавства (ідеться про технічний паспорт, сертифікат якості, інструкції 3 експлуатації тощо). Коли йдеться про експлуатацію транспортних засобів, чинним законодавством залежно від їх виду встановлюється обов'язкова вимога щодо 
наявності відповідних супроводжувальних документів, як необхідної передумови їх використання за цільовим призначенням.

Наявність страхового поліса в особи, яка здійснює управління згаданим засобом, іноді (залежно від виду транспорту) є обов'язковою умовою для використання його за цільовим призначенням (наприклад, у п. 2.1 Правил дорожнього руху визначено, що водій механічного транспортного засобу обов'язково повинен мати при собі (серед іншого) чинний страховий поліс (страховий сертифікат «Зелена картка») про укладення договору обов' язкового страхування цивільно-правової відповідальності власників наземних транспортних засобів) [14]. Отже, у визначених законом випадках до супроводжувальних документів, які надаються наймодавцем наймачеві разом із транспортним засобом, варто віднести і страховий поліс.

На наймодавця у відносинах прокату транспортного засобу зазвичай покладається обов'язок передати його в чистому вигляді й оброблений засобами дезінфекції, що є особливо актуальним під час світової пандемії COVID-19.

Також на наймодавця може бути покладено обов'язок передати наймачеві транспортний засіб iз певним рівнем палива (який з об'єктивних причин обмежений місткістю паливного бака або акумуляторної батареї (для електромобілів)).

Зрозуміло, що транспортний засіб, що передається наймодавцем наймачеві у прокат, не обов'язково має бути новим і в ідеальному стані. Транспортний засіб може мати і недоліки, але ці недоліки не повинні перешкоджати його використанню за цільовим призначенням. Тобто транспортний засіб та його обладнання мають відповідати вимогам, установленим чинним законодавством до таких об’єктів під час їх експлуатації (відповідність вимогам безпеки руху, екологічної безпеки тощо).

Наймодавець за договором прокату транспортних засобів є суб'єктом підприємницької діяльності і діє, серед іншого, керуючись нормативно встановленими правилами бухгалтерського обліку та звітності, а отже, приймання-передання транспортного засобу у прокат наймачеві повинно бути в будь-якому разі оформлено документально. У ст. 9 Закону України «Про бухгалтерський облік та фінансову звітність в Україні» [6] установлено, що підставою для бухгалтерського обліку господарських операцій є первинні документи. Зазвичай ці дії сторін оформлюються актом приймання-передачі транспортного засобу, який укладається сторонами. У згаданому акті здійснюється опис технічного стану транспортного засобу, можливих пошкоджень, показників приладів обліку, підтверджується його комплектність тощо.

Висновки. Передання транспортного засобу за договором прокату транспортного засобу може здійснюватися не лише шляхом активних дій наймодавця, прикладом чого може бути каршерінг.

Негайна (невідкладна) передача наймодавцем транспортного засобу у прокат є більш характерною для реального договору прокату транспортного засобу, тоді як у разі консенсуального договору строк передання транспортного засобу варто обумовлювати в договорі, оскільки між укладенням договору та переданням транспортного засобу в цьому разі все ж таки проходить певний період часу, хоча незначний, але розумно необхідний для вчинення сторонами відповідних дій.

Законом установлено вимоги щодо якості транспортного засобу, який передається в користування за договором прокату. Очевидно, що в разі, якщо транспортний засіб не відповідає нормативно встановленим вимогам до експлуатації в частині його технічного стану, комплектності, то його якість є неналежною, він не може бути переданий наймодавцем наймачеві за договором прокату, оскільки використання його за цільовим призначенням є неможливим.

\section{Jimepamypa}

1. Цивільний кодекс України : Закон від 16 січня 2003 р. № 435-IV. Відомості Верховної Ради України. 2003. № 40. Ст. 356.

2. Левенсон Д.С. Договор аренды транспортных средств. Москва : Юрид. лит., 1969. 120 с.

3. Мороз М.В. Правові питання оренди майна державних підприємств : дис. ... канд. юрид. наук: 12.00.03. Харків, 2000. 181 с.

4. Чуркін I.А. Договір найму (оренди) транспортного засобу без екіпажу : дис. ... канд. юрид. наук: 12.00.03. Харків, 2015. $194 \mathrm{c.}$

5. Що таке каршерінг авто. URL: https:// sollyplus.rent/uk/blog/chto-takoe-karsherynh/ (дата звернення: 05.06.2021).

6. Про бухгалтерський облік та фінансову звітність в Україні : Закон України від 16 липня 1999 р. № 996-XIV. Відомості Верховної Ради України. 1999. № 40. Ст. 365 (зі змінами).

7. Вакулович Е.В. Договір оренди транспортного засобу : дис. ... канд. юрид. наук: 12.00.03. Харків, 2002. 163 c.

8. Федорончук А.В. Договір прокату : дис. ... канд. юрид. наук: 12.00.03. Івано-Франківськ, 2015. 229 c.

9. Калаур I.P. Договірні зобов'язання про передання майна у користування в цивільному праві України : дис. ... докт. юрид. наук: 12.00.03. Київ, 2015. 452 c.

10. Про захист прав споживачів : Закон України від 12 травня 1991 р. № 1023-XII. Відолості Верховної Ради Української Радянської Соціалістичної Республі$\kappa и$. 1991. № 30. Ст. 379 (зі змінами).

11. Статут автомобільного транспорту УРСР, затверджений постановою Ради міністрів УРСР від 27 червня 1969 p. № 401. URL: https://zakon.rada.gov.ua/ laws/card/401-69-п.

12. Порядок надання в тимчасове користування громадянам предметів культурно-побутового та господарського вжитку : наказ Українського союзу об'єднань підприємств та організацій побутового обслугову- 
вання населення від 16 грудня 1999 р. № 46. Офіиійний вісник України. 2000. № 3. С. 189. Ст. 103.

13. Про транспорт : Закон України від 10 листопада 1994 р. № 232/94-ВР. Відолості Верховної Ради України. 1994. № 51. Ст. 466 (зі змінами).

14. Правила дорожнього руху, затверджені постановою Кабінету Міністрів України № 1306 від 10 жовтня 2001 р. Офіиійний вісник України. 2001. № 41. С. 35. Ст. 1852 (зі змінами).

\section{Анотація}

Тиндик М. П. Зміст обов'язку наймодавця з передання транспортного засобу за договором прокату транспортного засобу. - Стаття.

У статті проведено загальне дослідження й аналіз змісту обов'язку наймодавця 3 передання транспортного засобу за договором прокату транспортного засобу. Досліджено питання щодо якості транспортного засобу в момент передання його наймодавцем наймачеві, строку та місця передання транспортного засобу.

Автор наголошує на тому, що зміст і особливості виконання наймодавцем обов'язку з передання транспортного засобу у прокат зумовлені особливістю його предмета. Вимоги до стану окремих видів транспортних засобів, що визначають можливість їх використання, установлені законом. Також особливість цього предмета визначальним чином впливає на строк, місце та спосіб виконання досліджуваного обов'язку наймодавця.

Обгрунтовано положення про те, що передання транспортного засобу за договором прокату транспортного засобу може здійснюватися не лише шляхом активних дій наймодавця, прикладом чого може бути каршерінг.

Визначено, що велике значення для належного виконання обов'язку наймодавця з передання транспортного засобу в користування наймачеві має строк його виконання. Від строку виконання згаданого обов'язку наймодавцем залежить подальший розвиток правовідносин із прокату транспортного засобу, оскільки саме з моменту передання транспортного засобу в наймача з'являється можливість його використання та виникають відповідні обов'язки у правовідношенні з договору прокату (використовувати транспортний засіб за цільовим призначенням, забезпечувати його збереження в нормальному стані тощо).

Зазначено, що негайна (невідкладна) передача наймодавцем транспортного засобу у прокат $\epsilon$ характерною для реального договору прокату транспортного засобу, тоді як у разі консенсуального договору строк передання транспортного засобу варто обумовлювати в договорі, оскільки між укладенням договору та переданням транспортного засобу в цьому разі все ж таки проходить деякий період часу, хоча незначний, але розумно необхідний для вчинення сторонами відповідних дій.
Зроблено висновок про те, що законом встановлено вимоги щодо якості транспортного засобу, який передається в користування за договором прокату. Отже, якщо транспортний засіб не відповідає нормативно встановленим вимогам до експлуатації в частині його технічного стану, комплектності, то його якість є неналежною, він не може бути переданий наймодавцем наймачеві за договором прокату, оскільки використання його за цільовим призначенням $є$ неможливим.

Ключові слова: договір прокату транспортного засобу, наймодавець, обов'язок із передання транспортного засобу, якість транспортного засобу, комплектність транспортного засобу, місце передання транспортного засобу, строк передання транспортного засобу.

\section{Summary}

Tyndyk M. P. Contents of the lessor's obligation to transfer the vehicle under the vehicle rental agreement. - Article.

The article provides a general study and analysis of the content of the lessor's obligation to transfer the vehicle under the vehicle rental agreement. The question of the quality of the vehicle at the time of its transfer by the lessor to the lessee, the term and place of transfer of the vehicle are investigated.

The author emphasizes that the content and features the vehicle for rent are due to the peculiarities of its subject. Requirements for the condition of certain types of vehicles that determine the possibility of their use are established by law. Also, the peculiarity of this subject decisively affects the term, place and method of fulfillment of the researched duty of the lessor.

The provision that the transfer of a vehicle under a vehicle rental agreement can be carried out not only through the active actions of the lessor, an example of which is car sharing, is substantiated.

It is determined that the term of its performance is of great importance for the proper performance of the lessor's obligation to transfer the vehicle for use to the lessee. The further development of legal relations on vehicle rental depends on the term of performance of the mentioned duty by the lessor, as from the moment of transfer of the vehicle the lessee has a possibility of its use and there are corresponding obligations in legal relations under the contract of hire (to use the vehicle for special purposes, ensure its preservation in normal condition, etc.).

It is noted that the immediate transfer of the vehicle by the lessor is a characteristic feature of a real vehicle rental agreement, while in a consensual agreement the term of the transfer of the vehicle should be stipulated in the contract, as from the moment of the conclusion of the agreement to the moment of the transfer of the vehicle, nevertheless, a certain period of time passes, perhaps insignificant, 
but reasonably necessary for the parties to take appropriate action.

It is concluded that the law sets requirements for the quality of the vehicle, whic $h$ is transferred for use under the rental agreement. Therefore, if the vehicle does not meet the regulatory requirements for operation in terms of its technical condition, completeness, its quality is improper and it can not be transferred by the lessor to the lessee under the rental agreement, as its intended use is impossible.

Key words: vehicle rental agreement, lessor, obligation to transfer vehicle, quality of vehicle, completeness of vehicle, place of transfer of vehicle, term of transfer of vehicle. 